\title{
Assessment of Water Quality Using Benthic Macroinvertebrate along Sumber Maron River, District of Gondanglegi Kulon, East Java-Malang, Indonesia
}

\author{
Faiza Tawati ${ }^{1,2}$, Yenny Risjani ${ }^{3}$, Sasmito Djati ${ }^{4}$, Bagio Yanuwiadi ${ }^{4}$, Amin Setyo Leksono ${ }^{4}$ \\ ${ }^{1}$ Doctoral Program of Environmental Science, Postgraduate School, University of Brawijaya, Malang, Indonesia \\ ${ }^{2} \mathrm{Higher}$ Institute for Comprehensive Profession, Gharabuli, Libya \\ ${ }^{3}$ Faculty of Fisheries and Marine Sciences, University of Brawijaya, Malang, Indonesia \\ ${ }^{4}$ Department of Biology, Faculty of Mathematics and Natural Sciences, University of Brawijaya, Malang, Indonesia
}

\begin{abstract}
Human activities such as agriculture, swimming, livestock, public washing, and the use of latrines around the river are considered as major causes of damage to the river ecosystem, affecting the growth of Macroinvertebrate, and thus assessing the condition of the river. This study aimed to study the composition of Macroinvertebrate and the quality of water health in Sumber Maron River, in the village of Gondanglegi. This research was conducted from March to April 2018. The method used in this research was the quantitative method using primary data. Research stations were identified by considering land-use in nine regions. The sampling technique of total macroinvertebrates was the kicking technique using the manual mesh with a $500 \mu \mathrm{m}$ applied to the submerged solid substrates. The data were analyzed using a BMWP Index and interpreted by calculating the Average Scores Per Taxon (ASPT). The result of this research represented that there were 20 taxa of macroinvertebrates, which consisted of It belongs to 8 orders (Trichoptera, Coleoptera, Diptera, Tricladida, Decapoda, Odonata, Ephemeroptera, Plecoptera) and four class (Oligochaeta, Hirudinea, Gastropoda, Crustacea). Generally, the lowest taxa groups found in the station A1 (3 taxa), which were the agriculture and toilet (recreation area). Meanwhile, the highest taxa groups were found in station B3, which was the recreation area, by a total of 14 taxa. Macroinvertebrate with the lowest abundance was Gerridae at station $A 3$, which respectively had the number of 1 ind. $5 \mathrm{~m}^{-2}$. Macroinvertebrate with the highest abundance was Baetidae at the station B3, which is the recreation area, by the number of 549 ind $.5 \mathrm{~m}^{-2}$. The result of modified BMWP - ASPT analysis showed a value of 3.3-5.75, which indicated that the condition of Sumber Maron River was ranging from bad to excellent category. The bad water condition was found in the agriculture and toilet (recreation area), whereas the excellent water condition was found in the swimming pool (recreation area). Canonical Correspondence Analysis (CCA) revealed that environmental variables were significant for an explanation of the variance in the family.
\end{abstract}

Keywords: BMWP-ASPT, Macroinvertebrate, River.

\section{INTRODUCTION}

The river is open water that is easy to be influenced by the surrounding area, either naturally or from human activities. The river and its streams are an integral part of the watershed area. There are two important factors that can affect the river ecosystem, namely the constantly flowing water as well as the input of organic matter from the surrounding area. Sumber Maron River is an area that attracts visitors and tourists. It is one of the environmental tourism located in the south of Malang, where there are natural animals and plants.

Sumber Maron consists of three areas, the upstream, central, and estuary, each of which has

\footnotetext{
${ }^{*}$ Correspondence address:

Faiza Tawati

E-mail : fzaya2004@gmail.com

Address : Postgraduate School, University of Brawijaya, MT Haryono 169, Malang 65145.
}

different characteristics. The river water is used for household purposes, daily washing, cooking, bathing, and personal cleaning. The river is also used for swimming and recreation. Although Sumber Maron is an area of springs that must be protected and away from business activities or other activities that can harm the environment with the waste they produce, but along this attraction, there are many food stalls scattered with a variety of menus. While dining in this tourist area, especially in canned food, people may not be aware of dumping surrounding wastes and damaging.

Sumber Maron River contaminated in some areas due to waste from human activities. In addition, pollution comes from domestic, agricultural, and industrial waste. The most obvious result is an increase in the level of organic matter in water that is likely to decrease [1]. 
Pollutants are organic and inorganic substances derived from human activities around watersheds. Thus, water quality is affected. Furthermore, changes in water quality will affect the status and composition of the total living invertebrates of the river ecosystem. Macroinvertebrates are selected with their relatively stable characteristics as a biological indicator of water quality degradation due to the increasing activities human factors around watersheds. The community of these organisms has a rapid and consistent response to physical and chemical changes in water quality, thus can describe long-term environmental conditions [2].

In addition, the bioaccumulation study is not only used to detect environmental changes but can also provide river resource management options and recommendations for bioprospecting studies on species that can be selected as test animals [3]. The author, therefore, conducted research on bioassessment of the river using the BMP index to study the overall composition of invertebrates and determine the health status of the Sumber Maron River in Village of Kepanjen, East Java.

\section{MATERIAL AND METHOD}

This study used descriptive qualitative method. A qualitative method was used to explore a problem that occurred. The process of this method includes the submission of questions and procedures, as well as collecting specific data from the research object. A qualitative method was used to examine the natural objects (opposite of the experimental method). The natural object itself is the object that is happened and characterized naturally without any intervention or manipulation by the researcher [4]. In this study, a survey was conducted directly for the sampling of macroinvertebrates and river water at the predetermined research stations.

Sumber Maron River is located in the administrative area of Karangsuko Village, Malang regency. Sumber Maron is one of the river areas near the springs, which had been set as a tourism destination in Malang regency since 2007. The management of the tourism destination set the protection of a minimum of $\mathbf{2 0 0}$ meters from the spring. The elevation of the area is 300 and 337.5 meters above sea level. The temperatures range $17.25^{\circ} \mathrm{C}$ and $30.7^{\circ} \mathrm{C}$ with the precipitation on the

average of $1761 \mathrm{~mm}$ per year and the rainy duration of 84.85 days per year [5].

\section{Data Collection}

The method of data collection in this research was observation, which is elaboorated in the selection, alteration, recording and coding of a series of behaviors and circumstances regarding the in-situ organisms in accordance with empirical goals [6]. The observation was obtained by observing research locations along the upstream area of Sumber Maron River in Gondanglegi Village to collect macroinvertebrate and samples directly.

Sample was then assessed using modified index analysis of Biological Monitoring Working Party (BMWP). Furthermore, the observation of macroinvertebrate and measurement of water parameters were performed in the laboratory. The determination of sampling stations was based on the map used in the surrounding area of upped Sumber Maron River in Gondanglegi Village (Fig. 1).

A3

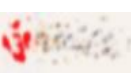

\section{$\mathrm{A} 2$}

B1

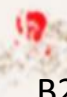

B2

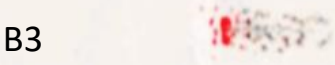

C1

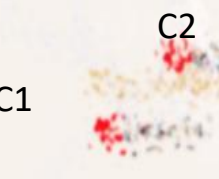

C3

Figure 1. Macroinvertebrates and Water Sampling Stations Description:

Upper Stream: A1, A2, A3

Middle Stream: B1, B2, B3

Downstream: C1, C2, C3

\section{Sampling Technique}

The macroinvertebrate sampling technique used the kicking method. Macroinvertebrate sampling tools and procedures were conducted in shallow waters allowing researchers to directly conduct direct sampling in rivers by using a wading suit, along $10 \mathrm{~m}$ in the riffle [1]. Brabander way of macroinvertebrate sampling was performed in an 
area of 10 to $20 \mathrm{~m}$ using a hand net, a mesh size of $500 \mu \mathrm{m}$ [7]. The sample was collected for 10 meters for each research station and was obtained on a shallow area of the river with a hard substrate. The preservation of samples was using containers with alcohol 96\%. Macroinvertebrates were identified to the family level.

\section{Data Analysis}

Analysis of the health status of Sumber Maron River is done after the identification of macroinvertebrate by calculating the composition and relative density of macroinvertebrate from each research station. Relative density is the percentage of individuals numbers per family divided to the total of individuals from the entire family of macroinvertebrate.

Macroinvertebrates are assessed using the BMWP (Biological Monitoring Working Party) index and calculated using the ASPT (Average Score Per Taxon). The results were then categorized according to the ASPT value. ASPT was calculated by dividing the score of the number of 1 family with the total number of the entire families from 1 sample [8]. ASPT score is categorized into six groups of interpretation (Table 1). Canonical Correspondence Analysis (CCA) with UPGMA cluster analysis also applied to reveal which environmental variables were significant to explain the variance in family abundance patterns.

$$
\text { ASPT }=\frac{\text { Total score of BMWP Index }}{\text { The number of the Family found }}
$$

Table 1. ASPT score category

\begin{tabular}{cc}
\hline ASPT Score & Water Quality \\
\hline$>6$ & Excellent \\
$5.5-6.0$ & Very Good \\
$5.0-5.5$ & Good \\
$4.5-5.0$ & Moderate \\
$4.0-4.5$ & Moderate - Poor \\
$>4.0$ & Poor \\
\hline
\end{tabular}

Source: Galbrand et al. [8].

\section{RESULT AND DISCUSSION \\ Environmental Parameters}

Water quality of Sumbermaron River at Gondanglegi Kulon Village, Malang, East Java described as follows. Substrates of the river base vary from large rocks, small stones, gravel, and sand. Physical and chemical properties are important for knowing water quality, as well as for supporting and assisting the life of macroinvertebrate. The results can be seen in
Table 4. Temperatures ranged from $23.7-24^{\circ} \mathrm{C}$ and are considered a good range for the aquatic organism (optimum $20-30^{\circ} \mathrm{C}$ ) [9]. The $\mathrm{pH}$ level of all stations is 7 and is still ideal for the ecosystem [10]. The hardness level ranged from 192-200 mg. $\mathrm{L}^{-1}$ and classified as hard water [9]. BOD 5 level ranged from 3.8-14.5 mg. $\mathrm{L}^{-1}$ classified as polluted for natural waters [11], and COD level ranged from 12.24$50.54 \mathrm{mg} . \mathrm{L}^{-1}$

Table 2. Physical and chemical indicators of each station

\begin{tabular}{lcccc}
\hline Prop. & Station (A) & Station (B) & Station (C) & WHO \\
\hline${ }^{\circ} \mathrm{C}$ & $23.97 \pm 0.153$ & $23.9 \pm 0.264$ & $23.8 \pm 0.200$ & 15 \\
$\mathrm{pH}$ & $7.47 \pm 0.208$ & $7.63 \pm 0.115$ & $8.4 \pm 0.96$ & $6.5-8.5$ \\
$\mathrm{BOD}$ & $8.51 \pm 4.34$ & $8.20 \pm 5.59$ & $6.28 \pm 3.74$ & 5 \\
$\mathrm{COD}$ & $30.12 \pm 19.28$ & $29.15 \pm 19.84$ & $23.85 \pm 14.19$ & 0.2 \\
$\mathrm{HD}$ & $200.67 \pm 5.03$ & $196.67 \pm 3.06$ & $194.0 \pm 5.29$ & 150 \\
\hline
\end{tabular}

Notes: Prop. $=$ physiscal and chemical properties, ${ }^{\circ} \mathrm{C}=$ temperature, $\mathrm{HD}=$ hardness.

\section{Macroinvertebrate Composition}

Observations of macroinvertebrate communities were conducted in the rainy and dry season. Parameters calculated in this study consisted of the abundance, relative density, richness, diversity, and composition. The results of observations of the macroinvertebrate composition were shown in Table 3 and Figure 2. There were 5389 individuals of macro-invertebrates collected in all stations. The abundance of the macro-invertebrates collected in the rainy season $(474.11 \pm 135.55)$ was higher than that in the dry season (124.67 \pm 53.52$)$ (Table 3). All dominant families' abundance had shown the same trend.

Table 3. Mean of abundance of Macroinvertebrata collected from all stations in rainy and dry seasons

\begin{tabular}{lcc}
\hline \multirow{2}{*}{ Family } & \multicolumn{2}{c}{ Season } \\
\cline { 2 - 3 } & $230.11 \pm 69.01$ & $46.67 \pm 32.99$ \\
\hline Baetidae & $89.89 \pm 43.66$ & $30.78 \pm 9.41$ \\
Hydrobiidae & $43.44 \pm 20.49$ & $22.33 \pm 10.56$ \\
Chironomidae & $33.22 \pm 13.83$ & $8.67 \pm 6.70$ \\
Hydropsychidae & $33.89 \pm 20.35$ & $5.22 \pm 3.72$ \\
Heptagenidae & $20.11 \pm 18.25$ & $0.22 \pm 0.22$ \\
Tipulidae & $4.67 \pm 2.59$ & $2.78 \pm 1.69$ \\
Atydae & $4.89 \pm 2.41$ & $0.89 \pm 0.56$ \\
Grapsidae & $3.56 \pm 1.36$ & $1.56 \pm 0.78$ \\
Elmidae & $3.89 \pm 1.79$ & 0 \\
Rhyachophilidae & $8.44 \pm 2.15$ & $7.56 \pm 2.90$ \\
Miscellenies & $474.11 \pm 135.55$ & $124.67 \pm 53.52$ \\
\hline Total abundance & &
\end{tabular}

Observations and identification conducted during the study showed that macroinvertebrates found in the Sumber Maron River consisted of 18 families in the rainy season and 16 families in the 
dry season. It belongs to 8 orders (Trichoptera, Coleoptera, Diptera, Tricladida, Decapoda, Odonata, Ephemeroptera, Plecoptera) and fourclass (Oligochaeta, Hirudinea, Gastropoda, Crustacea).

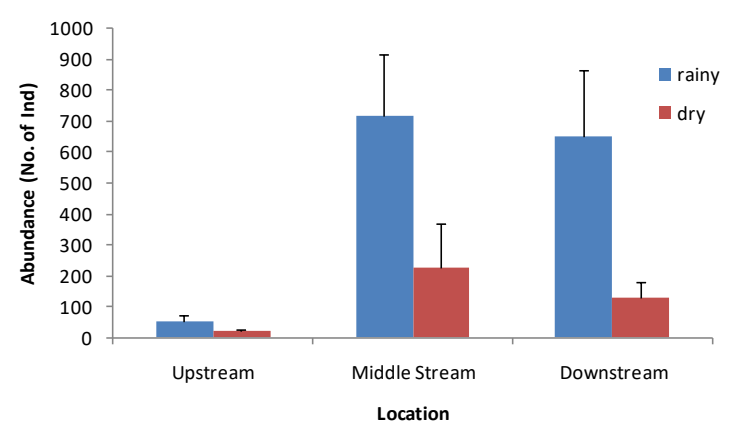

Figure 2. The abundance of macro-invertebrates in all locations both in rainy and dry seasons

The lowest mean of individuals was found in upstream both in the rainy season $(53.67 \pm 19.33$ individual) and in the dry season (19.61 \pm 4.04 individual). Meanwhile, the highest was found in the middle stream both in the rainy season (715.67 \pm 228 individual) and in the dry season (202.9 \pm 143.09 individual). The stations in upstream had the lowest abundance due to substrate that is dominated by sand and mud. Some species live among vegetations, and the others live in the mud. It is because the pillars of this station differed from sand and gravel to rock. Odum explained that flat and gravel environments are good environments for large invertebrates and an environment suitable for invertebrate growth [12].

The lowest mean of families was found in upstream, both in the rainy season $(5.67 \pm 1.76$ families) and in the dry season (4.66 \pm 0.88$)$. That station had the lowest number of taxa due to the substrate that is dominated by sand and mud. Some species live among vegetations, and the others live in the mud.

The highest number of families was found in the middle stream with the mean of $12.33 \pm 1.2$ families in rainy season dan $10.67 \pm 1.67$ families in the dry season. Those were including Chironomidae, Tipulidae, Baetidae, Caenidae, Hydropsychidae, Rhyacophilidae, Grapsidae, Atydae, Hydrobiidae, Valvatidae, Perlidae, Planaridae, Elmiidae, and Lumbriculidae. Substrates of this station were varied from sand, gravel to rocks. Flat stone and gravel are good environments for macroinvertebrates [12].

The lowest diversity was found in upstream, both in the rainy season $(1.18 \pm 0.18)$ and in the dry season $(1.12 \pm 0.13)$ Figure 3 . The highest diversity was found in the middle stream with the mean of $\mathrm{H}^{\prime}$ index was $1.42 \pm 0.05$ in dry season Figure 4 . Based on the score, the diversities of Macroinvertebrate were considered fair condition.

Statistical analysis of variance showed that the taxa richness $(F=12.94 ; \quad P<0.001)$ of macroinvertebrates were significantly higher in the middle stream, while there were no significant differences of the abundance and diversity between seasons and among locations. Several groups showed variation in the abundance between seasons and among locations. Baetidae, Hydrobiidae, and Rhyachophilidae responded to the seasons. Meanwhile, Baetidae, Hydrobiidae, Hydropsychidae, Atydae, and Rhyachophilidae responded to the locations. The interaction effect of season and location was significant to Hydrobiidae and Rhyachophilidae (Table 4). However, many families were not significantly different between season and among stations.

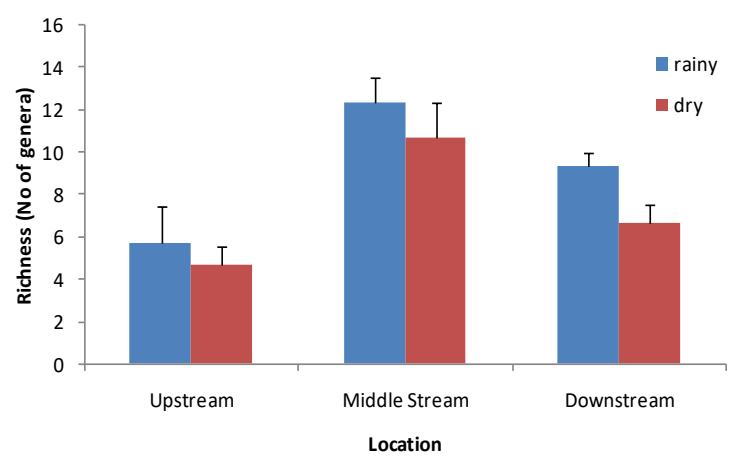

Figure 3. The taxa richness (number of families) of macroinvertebrates in all locations both in rainy and dry seasons

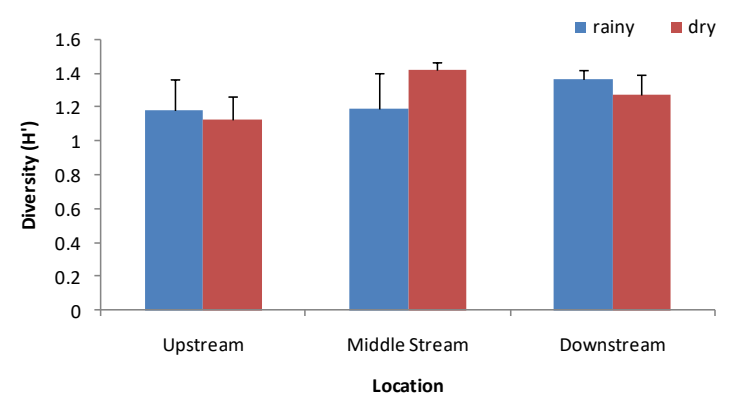

Figure 4. The diversity of macroincvertebrates in all locations both in rainy and dry seasons 
Tabel.4. Summary of $F$ values followed by degree of significance using ANOVA of the abundance, taxa richness and diversity of several Macroinvertebrate (Benthos) families

\begin{tabular}{llll}
\hline \multicolumn{1}{c}{ Group } & Season (S) & Location (L) & \multicolumn{1}{c}{ S*L $^{*}$} \\
\hline Baetidae & $13.22^{* *}$ & $9.31^{* *}$ & 3.08 \\
Hydrobiidae & $4.95^{*}$ & $10.77^{* *}$ & $5.84^{*}$ \\
Chironomidae & 0.76 & 0.84 & 0.41 \\
Hydropsychidae & 4.00 & $5.11^{*}$ & 1.45 \\
Heptagenidae & 2.00 & 1.23 & 1.12 \\
Tipulidae & 1.21 & 1.08 & 1.03 \\
Atydae & 0.54 & $5.19^{*}$ & 0.37 \\
Grapsidae & 2.24 & 0.24 & 0.63 \\
Elmidae & 1.27 & 0.25 & 0.05 \\
Rhyachophilidae & $36.03^{* * *}$ & $27.56^{* * *}$ & $27.56^{* * *}$ \\
Miscellenies & 0.09 & 3.35 & 1.81 \\
\hline Abundance & 9.95 & 5.82 & 2.03 \\
\hline Taxa richness & 3.05 & $12.94^{* * *}$ & 0.23 \\
\hline Diversity & 0.06 & 0.90 & 0.81 \\
\hline
\end{tabular}

Among the families, Baetidae, Hydrobiidae, Chironomidae, and Hydropsychidae were dominant in all stations both in rainy and dry seasons (Figure 5). These dominant families classified as a combination of moderate polluted groups, e.g. Hydropsychidae, Baetidae, and Gastropoda: Hydrobiidae, and heavily polluted, e.g. Chironomidae. Baetidae can be used as a bioindicator of mild pollution originating from organic materials. Based on the description of INP, it was concluded that the farther the spring was, the lower the organic material pollution level, or the better water quality of the channel, as indicated by the increase in the abundance of varieties in Baetidae.

Quingley [13] states that Chironomidae can be found in all types of water and prefer to live in mud. Chironomidae is tolerant of polluted water. Chironomidae can also be used as an indicator that the majority of the river's land is mud.

Diptera is a type of large invertebrate that loves to live in the mud substrate [14]. This means that the discovery of Chironomidae in large quantities means very suitable for gravel, sand, and mud. The Hirudinea group can withstand low oxygen levels and high levels of water pollutants [15]. It means the river polluted with high organic pollutants due to Planaridae found in it.

The result of the UPGMA cluster analysis showed that micro-invertebrate was assemblage according to season except in upstream. Macroinvertebrate compositions in rainy seasons between the middle stream and downstream branched at $56.1 \%$. Macroinvertebrate compositions in dry seasons between the middle stream and downstream branched at $51.5 \%$. Branching of the macroinvertebrate compositions in upstream between rainy and dry seasons occurred at $49.3 \%$. All compositions from two seasons and three locations had less than $20 \%$ similarity (Fig. 6).

The level of similarity between communities in the range of 40-60 is classified medium while under $40 \%$ is classified as low. It shows that macroinvertebrate spread is relatively uneven. This situation may because macroinvertebrates classified as sessile animals with relatively limited movement [16].
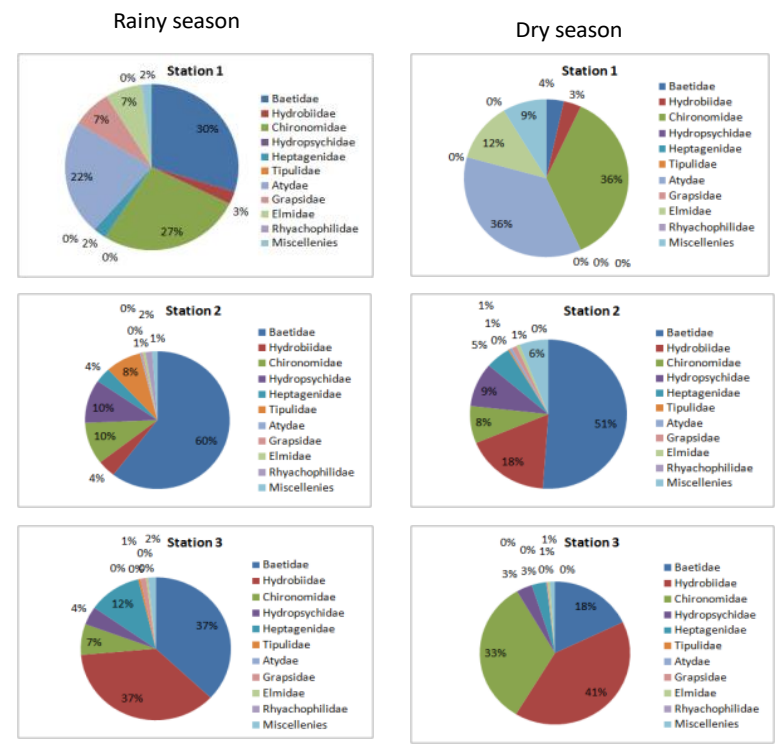

Figure 5. The number of macroinvertebrates families for each station in Sumber Maron River in rainy and dry seasons
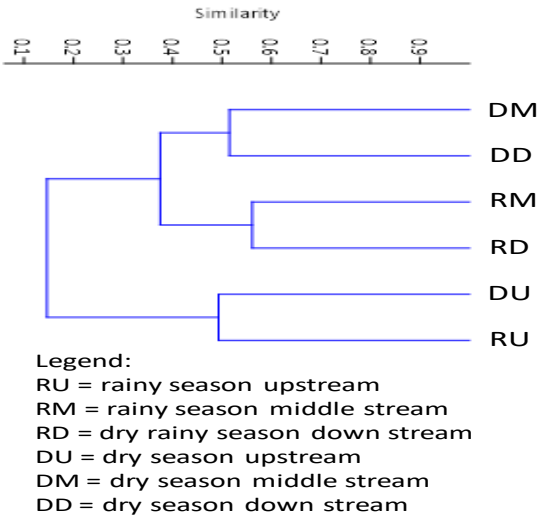

Figure 6. Community compositions between macroinvertebrate between rainy season and dry season and among the locations 
Canonical Correspondence Analysis (CCA) revealed that environmental variables were significant for the explanation of the variance in family abundance patterns (Fig. 7). The sum of the first two canonical eigenvalues was 0.45 . The first axis explained $46.4 \%$ of the family-environment relations, while the second explained $37.6 \%$ of the family-environment relations. All environmental factors had no significant effect on the familyenvironment $(P>0.05)$. It means the distribution of family abundance between season and among the sites was not influenced by environmental factors.

Although some families largely responded to the season, the environmental factor did not shape the formation in general. Pollution of the environment is one of the most important problems and challenges facing the world. Rivers are exposed to pollution as a result of the dumping of wastes loaded with biodegradable organic matter such as the remains of dead foods and animals and pesticide residues. Empty containers or toxic and hazardous chemicals containing pathogens found in rivers and valleys, the community is exposed to many diseases. It reduces the quality of freshwater for uses and becomes a barrier to human health, agriculture, and industry. Water pollution leads to a shortage and scarcity of environmental resources and health and social problems negatively affect the economic performance that will threaten food security.

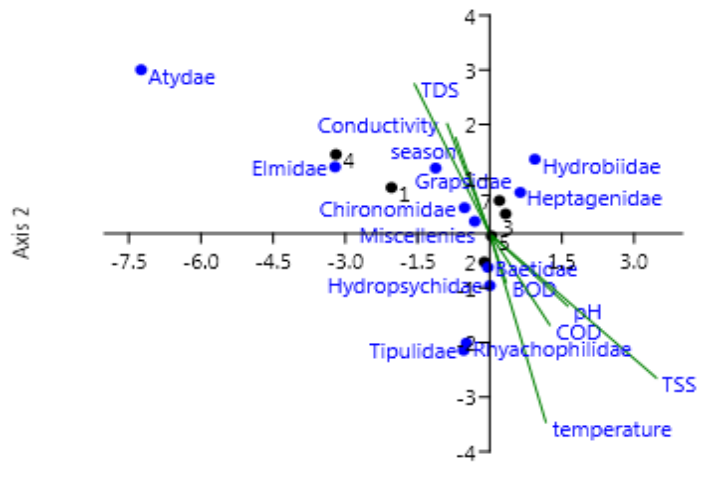

Axis 1

Figure 7. Analysis of CCA of macroinvertebrate family group in response to environmental variables

\section{Analysis of River Health Status}

The analysis of the health status of Sumber Maron River in Gondanglegi Village was obtained using the Biological Monitoring Working Party (BMWP) index and the calculation of ASPT. The result demonstrated a score of 3.33-5.75. It indicates that the water quality of the Sumber Maron River ranged from poor to very good quality. Based on the analysis by using the modification of the BMWP index, the result of the classification of macroinvertebrates in Sumber Maron River, Gondanglegi Village, Kepanjen obtained from the grouping of nine observation stations as in Table 4.

Table 4. Classification of macroinvertebrata in Sumber Maron River of nine stations

\begin{tabular}{lllc}
\hline No. & Station & ASPT & Water Quality Status \\
\hline 1 & Station A1 & 3.33 & poor \\
2 & Station A2 & 4.2 & moderate-poor \\
3 & Station A3 & 2.66 & poor \\
4 & Station B1 & 4.55 & moderate \\
5 & Station B2 & 4.71 & moderate \\
6 & Station B3 & 4.88 & moderate \\
7 & Station C1 & 4.8 & moderate \\
8 & Station C2 & 5.75 & very good \\
9 & Station C3 & 4.85 & moderate \\
\hline
\end{tabular}

The result of BMWP modification analysis that belongs to very good waters is station $\mathrm{C} 2$, which has ASPT value 5.75. The high value of ASPT at the station is due to Heptagenidae, Caenidae, and Perlidae. Water quality at station C2 is the current velocity as high as fast, high dissolved oxygen, type of large rock substrate, gravel, and sand. Plecoptera species are present among the litter, algae, or under rocks in flowing waters, usually found only in waters with high oxygen content, never present in polluted waters, to be used as biological indicators. Therefore, the presence of Trichoptera and Plecoptera larvae is used as an indicator that the aquatic environment is good $[17,18]$.

Although at station C2 is still very good waters, it has obtained a type of macroinvertebrate that has a low score, namely Chironomidae. A river dam has been created at this station for recreation purposes. It can contribute to the level of hardness derived from the use of soap.

The results of BMWP modification analysis that are classified as moderate water quality are station A2, B1, B2, B3, C1, and C3, which has an ASPT value ranging from 4.2 to 4.88 . Macroinvertebrates with the lowest scores were found at these stations because it was used as tourist attractions (pools). Tourists often swim and influence the substrate changes; the substrate is strongly related to life for macroinvertebrates [19]. If there is a rainy season, 
then the land on the plantation land will fall into the river that will cause changes to the bottom of the river basin into the mud, and mud is a good habitat for the Diptera class. Diptera is a type of macroinvertebrate that prefers to live on mud substrate, as well as most Chironomidae larvae found in a shallow pond, lake, and calm river [15].

The result of BMWP modification analysis, which classified as very bad (poor quality waters) are $\mathrm{A} 1$ and $\mathrm{A} 3$ stations, with $\mathrm{ASPT}$ value ranged between 3.33 and 2.66. Macroinvertebrates with the lowest scores have been found in this station. It is due to the discovery of Lumbriculidae type macroinvertebrates. Also, these stations have been used as tourist attractions (pools), where tourists often swim and influence substrate changes, where the substrate is strongly related to life for macroinvertebrates.

\section{CONCLUSION}

The chemical, physical, and biological properties of water quality in the Sumber Maron River were obtained as follows. The temperature ranged from $23.6-24.2^{\circ} \mathrm{C}$, the $\mathrm{pH}$ of the water was 7-9, hardness ranged between 190-206 mg. $\mathrm{L}^{-1}$, BOD ranged from $3.8-14.5 \mathrm{mg} . \mathrm{L}^{-1}$, COD ranges from 10.31-50.54 mg. $\mathrm{L}^{-1}$, and all results are within WHO standards.

The abundance of macroinvertebrates collected in the rainy season was higher than that in the dry season and all the dominant families' abundance showed the same trend. The macroinvertebrates found in the Sumber Maron River consisted of 18 families in the rainy season and 16 families in the dry season, which belong to 8 orders.

The result demonstrated a score of 3.33-5.75. It indicates that the water quality of the Sumber Maron River ranged from poor to very good quality.

\section{REFERENCES}

[1] Sudaryanti, S., Kusriani, Wijarni, M. Mahmudi, and E.Y. Herawati. 2003. Profile of student research results in 1998-2002. Program Study of Water Resource Management. Faculty of Fisheries and Marine Science, University of Brawijaya. Malang.

[2] Mulyanto. 1995. Makrobenthos sebagai indikator biologi perubahan kualitas air di Sungai Amprong Malang. Faculty of Fisheries and Marine Science, University of Brawijaya. Malang.

[3] Sudaryanti, S. 2002. Biodiversity of aquatic ecosystems for monitoring environmental conditions. Training of Land Management and Conservation. Center for Environmental Research, University of Brawijaya - BAPEDAL of East Java - Australia BEJIS Project. January 2002.

[4] Cantonati, M., K. Ortler. 1998. Using spring biota of pristine mountain areas for long-term monitoring. In: Hydrology, Water resources and Ecology in headwaters. Proceedings of the Head-Water '98 Conference. Meran/ Merano, Italy. IAHS Publ. 248. 379-385.

[5] Pandulu, G.D. 2015. Penataan ruang kawasan Sumber Air Jeruk dan Maron Kabupaten Malang. Jurnal Reka Buana.1(1). 10-18.

[6] Hasan, M.I. 2002. Pokok-pokok materi metodologi penelitian dan aplikasinya, $1^{\text {st }} \mathrm{Ed}$. Ghalia Indonesia. Jakarta.

[7] Sudaryanti, S., Marsoedi. 1995. Pendekatan biologis untuk menduga kualitas air Sungai Brantas Jawa Timur. Faculty of Fisheries and Marine Science, University of Brawijaya. Malang. Buletin Perikanan. 52.

[8] Galbrand, C., I.G. Lemieux, A.E. Ghaly, R. Cote, M. Verma. 2007. Assessment of constructed wetland biological integrity using aquatic macroinvertebrate. Online J. Biolo. Sci. 7(2). 52-65.

[9] Effendi, H. 2003. Telaah kualitas air, $5^{\text {th }}$ Ed. Kanisius. Yogyakarta.

[10] Barus, T. A. 2002. Pengantar limnologi. Department of Biology, Faculty of Mathematics and Sciences, University of North Sumatra. Medan.

[11] Republic of Indonesia. 2001. Government Regulation No. 82 year 2001 about water quality standards. Republic of Indonesia. Jakarta.

[12] Odum, E.P. 1993. Fundamentals of ecology, $3^{\text {rd }}$ Ed. Samingan, T. (transl). Gadjah Mada University Press. Yogyakarta.

[13] Quigley, M. 1977. Invertebrates of streams and rivers: a key to identification. Edward Arnold. Nene College. Northampton.

[14] Hawking, F.J. Smith 1997. Colour guide to invertebrates of Australian inland water. Identification Guide Freshwater Ecology. 
Murray Darling Freshwater Research Centre. Albury NSW.

[15] Gooderham, J., E. Tsyrlin. 2002. Waterbug book: a guide to the freshwater macroinvertebrates of temperate Australia. DOI: 10.1071/9780643090026.

[16] Ormerod, S.J., R.W. Edwards. 1987. The ordination and classification of macroinvertebrate assemblages in the catchments of the River Wye in relation to environmental factors. Freshwat. Biol. 17. 533-546.

[17] Awuy, N.H.S., S. Sudaryanti. 2003. Pemberdayaan komunitas makrozoobenthos untuk Pengelolaan Sungai Lang-lang Kecamatan Singosari, Kabupaten Malang, Jawa Timur. National Seminar Faculty of Mathematics and Science. Sepuluh Nopember Institute of Technology, Surabaya.

[18] Patang, F., A. Soegianto, S. Hariyanto. 2018. Benthic macroinvertebrates diversity as bioindicator of water quality of some rivers in East Kalimantan, Indonesia. Int. J. Ecol. Article ID 5129421, 11.

[19] Boyero, L. 2003. The quantification of local substrate heterogeneity in streams and its significance for macroinvertebrate assemblagess. Hydrobiologia. 499. 161-168. 